ZOOLOGIA 28 (6): 693-700, December, 2011

doi: $10.1590 /$ S1984-46702011000600001

\title{
Thermal ecology and thermoregulatory behavior of Coleodactylus natalensis (Squamata: Sphaerodactylidae), in a fragment of the Atlantic Forest of Northeastern, Brazil
}

\author{
Pablo A. G. de Sousa ${ }^{1,2} \&$ Eliza M. X. Freire ${ }^{1}$ \\ ${ }^{1}$ Laboratório de Herpetologia, Departamento de Botânica, Ecologia e Zoologia, Centro de Biociências, Universidade Federal \\ do Rio Grande do Norte.59072-970 Natal, RN, Brazil.E-mail: pabloguitar2@hotmail.com; elizajuju@ufrnet.br \\ 2 Programa de Pós-Graduação em Psicobiologia, Centro de Biociências, Universidade Federal do Rio Grande do Norte. \\ 59072-970 Natal, RN, Brazil.
}

\begin{abstract}
We studied the thermal ecology and thermoregulatory behavior of Coleodactylus natalensis Freire, 1999 in a remnant of a northern coastal patch of the Brazilian Atlantic Forest. Data were collected during four 20-day field excursions over the course of one year. We assessed the importance of substrate and air temperatures, in addition to time of exposure to sunlight, as relevant factors for the regulation of body temperature in this species. After each specimen was captured, body ( $\mathrm{Tb}$ ), substrate ( $\mathrm{Ts}$ ) and air ( $\mathrm{Ta}$ ) temperature were measured $10 \mathrm{~cm}$ above the ground, using a temperature sensor coupled to a fast response thermo-hygrometer. Ad libitum and focal animal methods were used to describe thermoregulatory behavior. The mean body temperature of $\mathrm{C}$. natalensis was $31.3 \pm 3^{\circ} \mathrm{C}$ (amplitude of 26.9 and $38.4^{\circ} \mathrm{C}$, $\mathrm{n}=20$ ). A positive relationship was found between $\mathrm{Tb}$ and environmental temperatures; further, substrate temperature explained the additional variability of temperature variations in this species. With respect to environmental observations, individuals of $C$. natalensis did not expose themselves directly to the sun, moving equally between full and filtered sun. Our results indicate that $C$. natalensis is umbrophylic and a passive thermoregulator.
\end{abstract}

KEY WORDS. Atlantic Forest; behavior; umbrophyle species.

Like other ectothermal animals, lizards depend on environmental sources to absorb heat (PIANKA \& VITT 2003). They use environmental mechanisms to adjust their body temperature and maintain it within a range that meets their physiological and ecological needs (Cowles \& Bogert 1944, Huey 1982). The thermoregulatory behavior of a lizard involves costs and associated benefits, which reflect individual ecological and thermoregulatory priorities (Huey \& Statkin 1976, Downes \& SHINE 1998).

Behavioral regulation of body temperature can be achieved through different mechanisms of sun exposure (Cowles \& BOGERT 1944, Bogert 1959, Pianka 1971, Huey et al. 1977, Rocha 1988, Rocha \& Bergallo 1990). These mechanisms play an important role in the active temperature regulation of individual animals (Huey \& Slatkin 1976). In passive thermoregulation, body temperatures generally reflect environmental temperatures. Active and passive thermoregulation strategies can be considered as the two extremes of a continuum of thermoregulatory options (Huey \& Slatkin 1976). Body temperature regulation is therefore a complex process, influenced not only by environmental heat sources, but also by the ecological and life history characteristics of the species (Rocha 1994, Kiefer et al. 2005, 2007, Rocha et al. 2009).
In Brazil, most thermal ecology studies have been conducted in open formations such as Restingas (Rосна 1988, 1994, 1995, Van Sluys 1992, Bergallo \& Rocha 1993, Vrcibradic \& Rocha $1996,1998)$, Cerrado and in areas of Savanna in the Amazon territory (Vitt 1991, Colli \& Paiva 1997, Mesquita \& Colli 2003, Mesquita et al. 2006a, b) and Caatingas (Vitt 1995, Vitt \& Carvalho 1995, Freire et al. 2009, Ribeiro \& Freire 2010), while research in forest areas has concentrated on the Amazon Region (MaGNusson et al. 1985, Rocha \& Bergallo 1990, Vitt \& Zani 1998, VitT et al. $1997,2000,2005)$. There is an obvious scarcity of studies on the thermal ecology of lizards in the Atlantic Forest.

Coleodactylus natalensis Freire, 1999 (Fig. 1) was initially described as endemic to the Parque Estadual das Dunas de Natal, and is considered to be endemic to the Rio Grande do Norte Atlantic Forest. It is a diurnal lizard that inhabits leaf litter in shady areas (Freire 1999, Capistrano \& Freire 2009), making it a forest species restricted to the Atlantic Forest biome. Other than a description of the species (Freire 1999), few ecological studies have been conducted involving reproduction, habitat use, predation, activity period and diet (Lisboa et al. 2008, Capistrano \& Freire 2009, Sousa \& Freire 2010, Sousa et al. 2010).

The aims of our study were to: (I) evaluate mean body temperature of active C. natalensis in an Atlantic Forest rem- 
nant; (II) identify environmental factors involved in the thermoregulation process of this species, and (III) quantify exposure time to sunlight, as determinant factors for regulating body temperature.

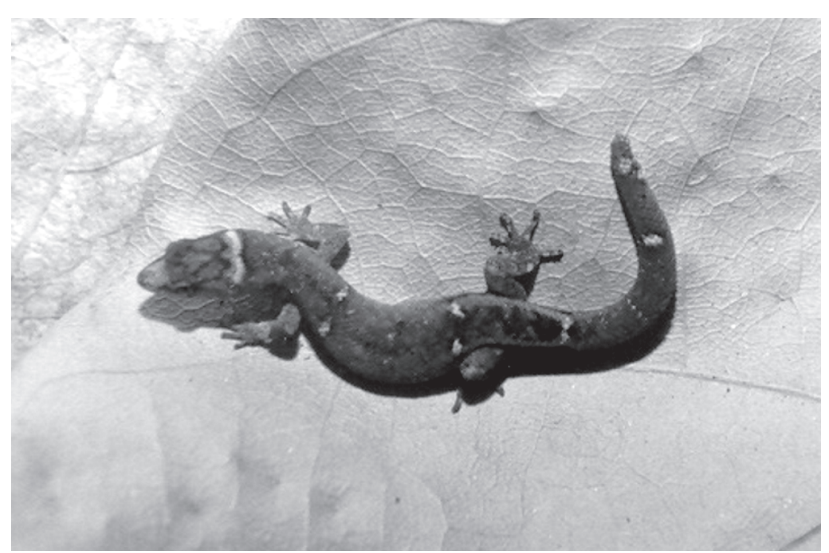

Figure 1. Coleodacylus natalensis Freire, 1999. Photo by Helianne de Niemeyer.

\section{MATERIAL AND METHODS}

Data were collected in a remnant of the Brazilian Atlantic Forest, the Parque Estadual Mata da Pipa (PEMP $-6^{\circ} 14^{\prime} \mathrm{S}$ and $35^{\circ} 03^{\prime} \mathrm{W}$, Fig. 2). It is located in the Municipality of Tibau do Sul, state of Rio Grande do Norte, covering an area of approximately 290 ha (Rio Grande do Norte 2006) at $63 \mathrm{~m}$ above sea level.

The climate of the region is classified as sub-humid with a mean temperature of $26.5^{\circ} \mathrm{C}$ (maximum $32^{\circ} \mathrm{C} /$ minimum $21^{\circ} \mathrm{C}$ ), mean annual relative humidity of $74 \%$ and highest rainfall levels in April and June. The soil is predominantly composed of dystrophic quartz sands, which are relatively flat and excessively drained and deep with extremely low natural fertility and a sandy texture (EMPARN 2010).

We conducted four 20-day field excursions (two in the rainy season: October 29 to November 182008 and October 8282009 and two in the dry season: March 4-24 2008 and July 1-21 2008), totaling 80 days of daytime (between 0700 and 1800). Individuals were located by means of active searches in the high forest of PEMP. The percale area used during field work contains large trees (above $15 \mathrm{~m}$ ) with diameters breast high

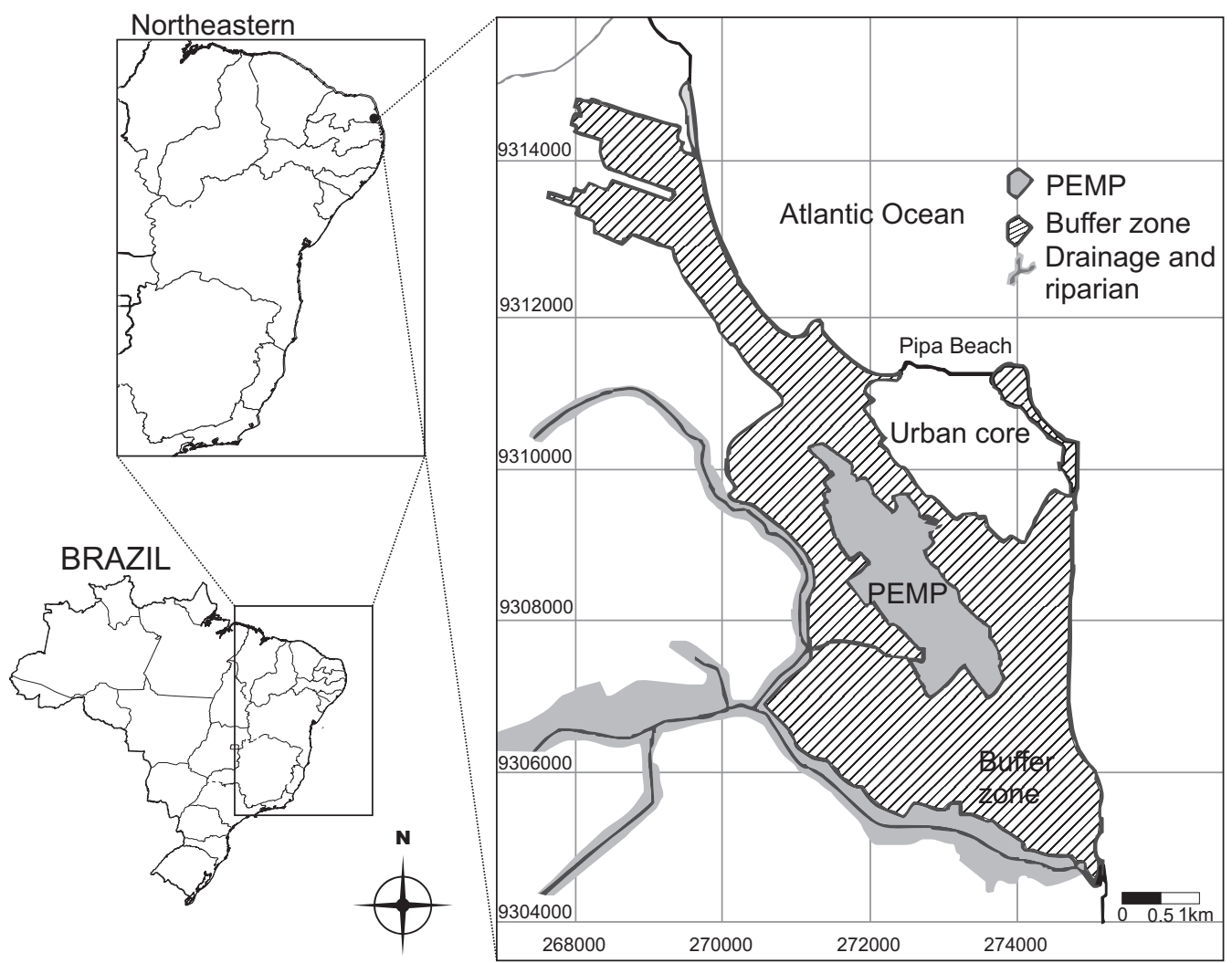

Figure 2. Location of the Parque Estadual Mata da Pipa (PEMP), municipality of Tibau do Sul, state of Rio Grande do Norte, northeastern Brazil. 
(DBH) of over one meter and a canopy that blocks out most of the sunlight, except for some areas with clearings resulting from numerous tree falls. The litter is thick and abundant with extensive resprouting of the underbrush.

We explored four $500 \mathrm{~m}$ transects in the habitat. Those were located $50 \mathrm{~m}$ apart and crossed the area in a mainlandsea direction. Transects were traversed in a linear fashion, deviating $5 \mathrm{~m}$ to the right or left every $10 \mathrm{~m}$ in order to better cover the microhabitats used by these specimens. Individual animals were collected manually.

When studying C. natalensis specimens, behavioral observations were made ad libitum (AlTMANn 1974), to record behavioral activities at regular time intervals. The focal animal method (Altmann 1974), by which a single individual is observed for a given length of time to record behavior frequency and duration, was also used. We recorded the length of time the animals were exposed to three categories of sunlight: shade, filtered sun and direct sunlight (Figs 3, 4, and 5 respectively), as well as the length of time during which animals were motionless or moving. In both methods, 5-minutes observation intervals were established, followed by an additional five minutes for recordings.

At the moment of capture we measured cloacal temperature (considered as body temperature - Tb), as well as substrate (Ts) and air (Ta) temperature $\left({ }^{\circ} \mathrm{C}\right) 10 \mathrm{~cm}$ above ground. This procedure was performed with the help of a temperature sensor (Instruterm ${ }^{\circledR}$ model S-02K) coupled to a digital thermo-hygrometer (Instruterm ${ }^{\circledast}$ model HTR-160 - accurate to $0.1^{\circ} \mathrm{C}$ and 1 -s response time). Only body temperatures obtained up to ten seconds after capture were considered. The collected specimens were deposited in the Coleção Herpetólogica do Departamento de Botânica, Ecologia e Zoologia (CHBEZ), Universidade Federal do Rio Grande do Norte (UFRN).

We calculated mean body temperature of active $C$. natalensis as the arithmetic mean of cloacal temperatures recorded for all the lizards collected. The paired t-test was used to evaluate whether there was a significant difference between air and substrate temperatures recorded for the species. Body temperature dependency ( $\mathrm{Tb}$, dependent variable) in relation to that recorded in the microhabitat (Ts and Ta, independent variables) was determined by simple linear regression. If a significant correlation was found, multiple linear regression was carried out using the stepwise method to evaluate if either of the two environmental variables (Ta and Ts) explains an additional variation in the lizard's body temperature (DANCEY \& REIDY 2006).

To estimate the degree of behavioral thermoregulation (passive or active thermoregulator), we used the absolute values of the differences between $\mathrm{Tb}$ and $\mathrm{Ta}(\Delta \mathrm{TA})$ and between Tb and Ts ( $\Delta$ TS) in the module (Vrcibradic \& Rocha 1998, Kiefer et al. 2007). The Wilcoxon non-parametric test was used to compare the $\Delta \mathrm{TA}$ and $\Delta \mathrm{TS}$ values (DANCEY \& ReIDy 2006). All statistical procedures were calculated with the aid of the software SPSS 15.0 for Windows.
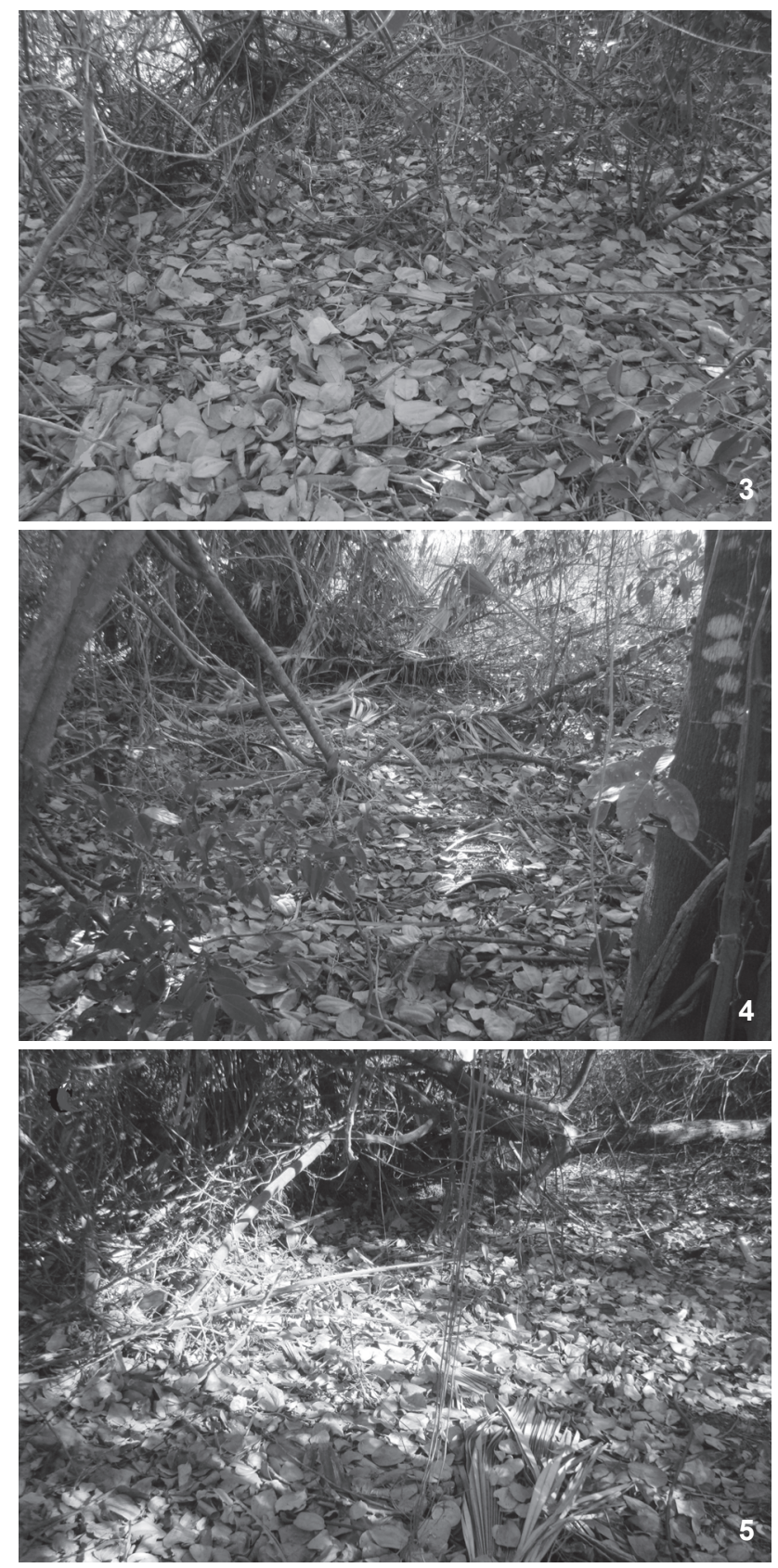

Figures 3-5. General aspect of the litter (3) in shade, (4) under filtered sun and (5) exposed to sunlight.

\section{RESULTS}

We observed 76 Coleodactylus natalensis individuals, all found in leaf litter (44 collected) during the four excursions; the body temperatures of 20 specimens were considered for analysis (Tab. I). Mean body temperature for the species during 
activity was $31.3 \pm 3^{\circ} \mathrm{C}\left(26.9-38.4^{\circ} \mathrm{C} ; \mathrm{n}=20\right)$ while mean air and substrate temperatures were $28.1 \pm 3.8^{\circ} \mathrm{C}$ and $28.2 \pm 3.7^{\circ} \mathrm{C}$, respectively (Tab. I). There was no significant difference between environmental temperatures (air and substrate $\mathrm{t}_{19}=-0.37, \mathrm{p}=0.713$, Tab. I).

A significant, positive correlation was found between body (Tb) and air temperatures (Ta, $\mathrm{r}^{2}=0.588, \mathrm{p}<0.001$, Tab. I, Fig. 6). The same relationship was found between body (Tb) and substrate temperatures (Ts, $\mathrm{r}^{2}=0.591, \mathrm{p}<0.001$, Tab. I, Fig. 7). However, after disregarding the effect of air temperature, substrate temperature explains part of the additional variation in body temperature during activity.
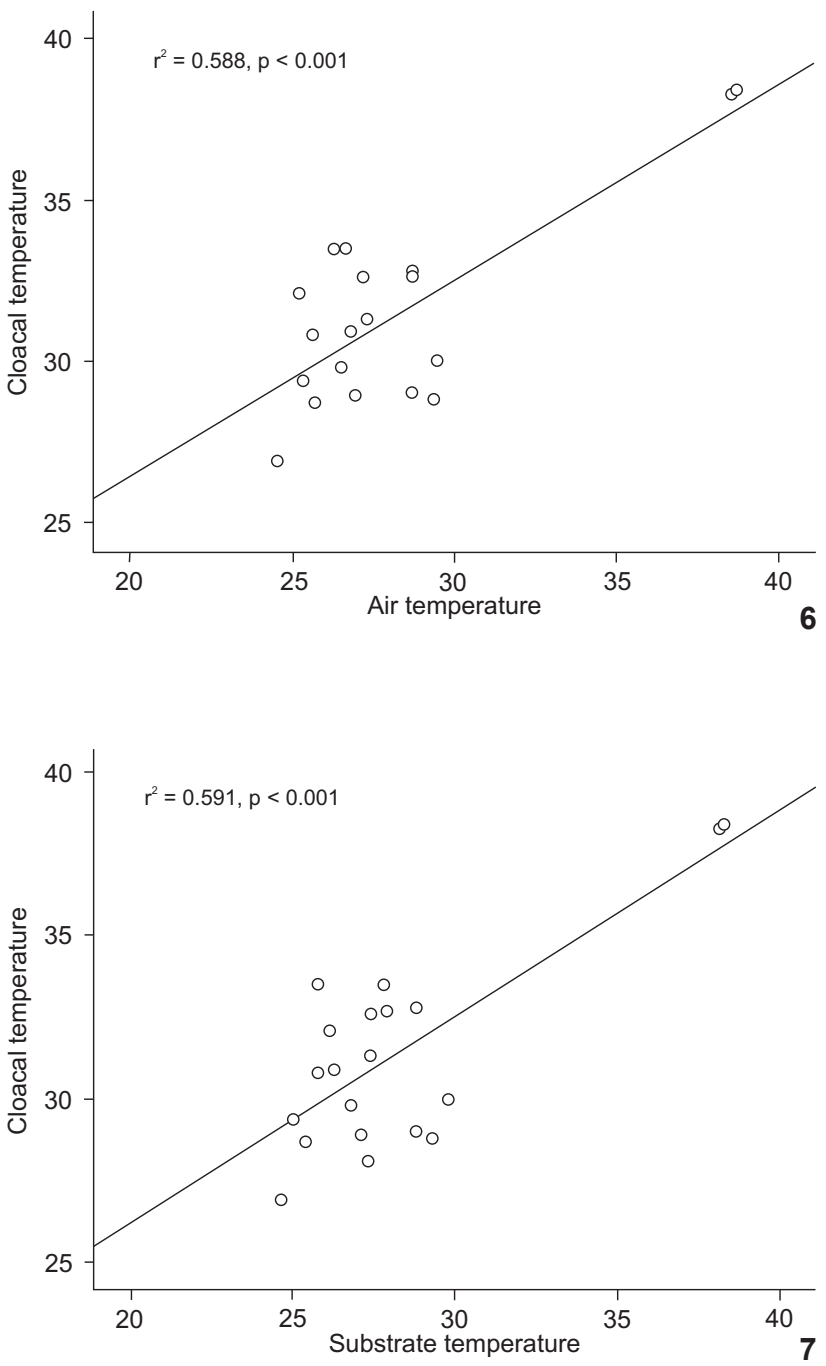

Figures 6-7. Relationships between body temperature of active Coleodactylus natalensis and environmental temperatures in the Parque Estadual Mata da Pipa, Tibau do Sul, Rio Grande do Norte, Brazil: (6) air temperature; (7) substrate temperature.
With respect to the degree of behavioral thermoregulation (Fig. 8), median $\Delta \mathrm{TA}\left(\mathrm{M}=3.6^{\circ} \mathrm{C}, \mathrm{n}=20\right.$, Tab. I) and $\Delta \mathrm{TS}$ $\left(3.6^{\circ} \mathrm{C}, \mathrm{n}=20\right.$, Tab. I) values were equal, with no significant difference among the remaining values (paired Wilcoxon, $\mathrm{T}=15.17$, $\mathrm{z}=-0.525, \mathrm{p}=0.600$ ). The highest percentage of negative values was recorded for $\Delta \mathrm{TA}(15 \%)$, while for $\Delta \mathrm{TS}$ it was only $5 \%$.

Table I. Mean body temperature (Tb) of active Coleodactylus natalensis $(n=20)$, mean air $(T a)$ and substrate $(T s)$ temperatures and median values of the module of differences between $\mathrm{Tb}$ and $\mathrm{Ta}(\Delta \mathrm{Ta})$ and between $\mathrm{Tb}$ and $\mathrm{Ts}(\Delta \mathrm{Ts})$ recorded in the lizard microhabitats, including a summary of paired t-test and simple and multiple linear regressions between the temperatures, as well as the paired Wilcoxon test between $\Delta T A$ and $\Delta T S$.

\begin{tabular}{llll}
\hline \multicolumn{3}{c}{ Temperatures } & \multicolumn{2}{c}{ Statistical tests } \\
\hline $\mathrm{Tb}$ & $31.3 \pm 3^{\circ} \mathrm{C}$ & $\mathrm{t}$-test & $\mathrm{t} 19=-0.37 ; \mathrm{p}=0.713$ \\
$\mathrm{Ts}$ & $28.2 \pm 3.7^{\circ} \mathrm{C}$ & $\mathrm{Tb}$ vs Ta & $\mathrm{r}^{2}=0.588 ; \mathrm{p}<0.001$ \\
$\mathrm{Ta}$ & $28.1 \pm 3.8^{\circ} \mathrm{C}$ & $\mathrm{Tb}$ vs Ts & $\mathrm{r}^{2}=0.591 ; \mathrm{p}<0.001$ \\
$\Delta \mathrm{TA}$ & $3.6^{\circ} \mathrm{C}$ & Tb vs Ta vs Ts & $\mathrm{r}^{2}=0.484 ; \mathrm{F} 1,10=9.39 ;$ \\
& & & $\mathrm{p}=0.012 ; \mathrm{pTa}=0.012 ;$ \\
& & $\mathrm{pTs}=0.961$ \\
$\Delta \mathrm{TS}$ & $3.6^{\circ} \mathrm{C}$ & $\Delta \mathrm{TA}$ vs $\Delta \mathrm{TS}$ & $\mathrm{T}=15.17 ; \mathrm{Z}=-0.525 ;$ \\
& & & $\mathrm{p}=0.600$ \\
\hline
\end{tabular}

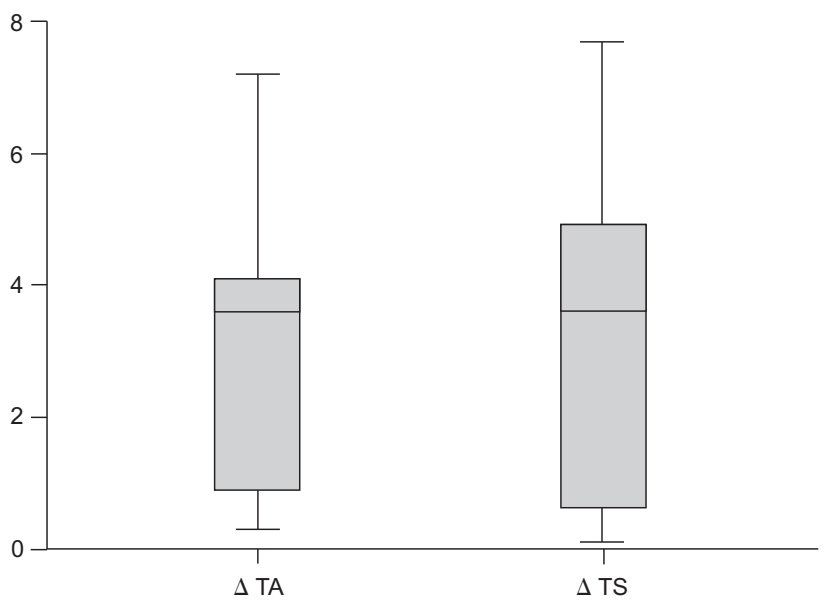

Figure 8. Absolute values of the differences between $\mathrm{Tb}$ and $\mathrm{Ta}$ $(\Delta T A)$ and between $\mathrm{Tb}$ and Ts $(\Delta T S)$ in the module for Coleodactylus natalensis $(\mathrm{N}=20)$ in Parque Estadual Mata da Pipa, Tibau do Sul, Rio Grande do Norte, Brazil.

Our behavioral observations totaled 16 minutes and 20 seconds ( $n=9$; Tab. II). Coleodactylus natalensis individuals did not expose themselves directly to sunlight in the clearings and were primarily found moving between shade (72.4\%) and filtered sun $(27.6 \%$, Tab. II). These observations were supplemented by the fact that $53.9 \%(n=41)$ of the total number of 
individuals of $C$. natalensis observed $(\mathrm{n}=76)$ were found in shaded areas. The remaining animals $(46.1 \% ; \mathrm{n}=35)$ were spotted under filtered sun (Fig. 9).

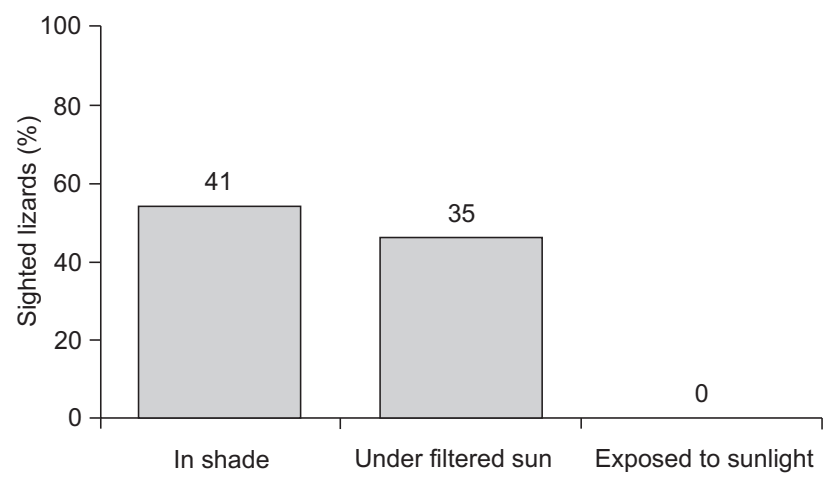

Figure 9. Frequency distribution of active Coleodactylus natalensis ( $n=76$ ) under different sunlight exposure conditions in Mata da Pipa State Park, Tibau do Sul, Rio Grande do Norte, Brazil. Numbers on top of bars indicate sample sizes.

\section{DISCUSSION}

The mean body temperature recorded for $C$. natalensis (Tab. I) was considered high when compared with estimates for an Amazonian congener, C. amazonicus (estimated in $27^{\circ} \mathrm{C}$, based on temperatures in the microhabitats where they are found (VitT et al. 2005, 2008) and with other species of Sphaerodactylidae, such as Gonatodes humeralis (Guichenot, 1855) (28.4 and $30.3^{\circ} \mathrm{C}$, Virt et al. 1997 , VitT et al. 2000, respectively) and $G$. hasemani $\left(30.6^{\circ} \mathrm{C}\right.$, VITT et al. 2000).

According to BratTSTrom (1965) and Licht et al. (1966), phylogenetically close lizard species tend to have similar body temperatures, even when living in different habitats. However, the type of habitat is also an important factor influencing body temperature (Pianka 1977, Jaksic \& SChwenk 1983, Magnusson 1993). In some cases, a species living in habitats with lower environmental temperatures may also have lower body temperatures than conspecifics in habitats where higher temperatures prevail (Kiefer et al. 2005, KoHLSDORF \& NAVAS 2006). The body temperature recorded for $C$. natalensis, an umbrophile species, may be due to the fact that minute species such as the Sphaerodactylidae exhibit high rates of water loss in relation to their small size and, consequently, greater capacity to absorb heat (Maclean 1985, Steinberg et al. 2007). Furthermore, this species shows tolerance to less shaded areas, as a pre-adaptive trait to warmer environments (FreIRE 1999), which might explain the high body temperatures recorded in two individuals who had body temperatures that possibly fled to the standard population (Figs 6 and 7). However, they were collected in a poorly shaded spot, near the forest edge, where the ambient temperatures were high, confirming that this species is tolerant to warmer environments.

To date, body temperature records for Coleodactylus are nonexistent, since species of this genus are the smallest among all lizards. Their small size hinders the use of methods routinely employed for lizards (ViтT et al. 2005). However, the mean temperature recorded for the substrate used by $C$. natalensis (Tab. I) did not differ from that recorded for the substrate of Amazonian congeners (C. amazonicus and C. septentrionalis VITT et al. 2005), or from the population of $C$. natalensis studied in its type-locality (Capistrano \& Freire 2009).

The body temperature of $C$. natalensis showed a significant relationship with the temperatures recorded at the capture site (Figs 6 and 7), which suggests that the individuals use behavior to maintain a certain degree of control over their temperature (VITT \& CARVALHO 1992). Since substrate temperature offers the best explanation for body temperature variations, we suggest that this species has a thigmothermal behavior. The high proportion of individuals with $\mathrm{Tb}$ above Ts, along with the fact that no specimens were seen directly exposed to sunlight (Fig. 9), suggests that this species exhibits a certain degree

Table II. Length of exposure to light conditions and movement for Coleodactylus natalensis $(n=9)$.

\begin{tabular}{clllll}
\hline Individual observed & \multicolumn{1}{c}{ In shade } & \multicolumn{1}{c}{ Movement } & Under filtered Sun & Movement & Total time \\
\hline 1 & $00: 01: 45 \mathrm{~s}$ & In motion & $00: 02: 15 \mathrm{~s}$ & In motion & $00: 04: 00 \mathrm{~s}$ \\
2 & $00: 02: 00 \mathrm{~s}$ & In motion & - & - & $00: 02: 00 \mathrm{~s}$ \\
3 & $00: 00: 45 \mathrm{~s} / 00: 00: 15 \mathrm{~s}$ & Motionless/In motion & - & - & $00: 01: 00 \mathrm{~s}$ \\
4 & - & - & $00: 01: 00 \mathrm{~s}$ & In motion & $00: 01: 00 \mathrm{~s}$ \\
5 & $00: 00: 30 \mathrm{~s}$ & In motion & - & - & $00: 00: 30 \mathrm{~s}$ \\
6 & $00: 02: 00 \mathrm{~s}$ & In motion & - & - & $00: 02: 00 \mathrm{~s}$ \\
7 & $00: 02: 10 \mathrm{~s} / 00: 00: 50 \mathrm{~s}$ & In motion/Motionless & - & - & $00: 03: 00 \mathrm{~s}$ \\
8 & $00: 01: 35 \mathrm{~s}$ & Motionless & - & - & $00: 01: 35 \mathrm{~s}$ \\
9 & - & - & $00: 02: 15 \mathrm{~s}$ & In motion & $00: 02: 15 \mathrm{~s}$ \\
\hline Total & $00: 11: 50 \mathrm{~s}(72.44 \%)$ & & $00: 05: 30 \mathrm{~s}(27.56 \%)$ & $00: 16: 20 \mathrm{~s}(100 \%)$ \\
\hline
\end{tabular}


of thermoconformity (Bogert 1949, 1959, Patterson \& Davies 1978, Magnusson et al. 1985, Kiefer et al. 2007), with $\Delta$ TS values tending to be greater than those of $\Delta \mathrm{TA}$ (Fig. 8). Coleodactylus natalensis prefer forest habitats in shadier areas without direct sunlight, with milder temperatures, and more abundant litter (CAPISTRano \& Freire 2009). This preference for more mesologic habitats is shared with other Coleodactylus species in different biomes (VANZolini et al. 1980, VitT \& ZANi 1998, Colli et al. 2002, VITT et al. 2005).

The use of habitat by lizards has been mainly studied in the context of interspecific competition and niche partitioning, without considering the thermoregulatory restrictions in microhabitat use (Grover 1996). However, some characteristics of habitats and (shade level and presence of water bodies) microhabitats used by lizards have an important influence on the food and thermal ecology of these animals (GANDOLFI \& Rocha 1998, Huey 1982, Rocha 1994, Van Sluys 1992, VRcibradic \& Rocha 1998).

The thermal patterns of lizards may be influenced by phylogenetic and foraging factors, body size, activity period and habitat (HuEy \& Pianka 1983, Pianka 1986, Rocha 1994, Rocha et al. 2009). The low mean temperature recorded during activity for lizard species from forest areas may be due to the lower availability of thermal sources for thermoregulation, as well as lower microhabitat temperatures, compared to open environments (Howland et al. 1990, VitT 1991, VitT et al. 1997, 1998). Our data, therefore, corroborate findings that the thermal characteristics of species are a result of environmental factors and are regulated by behavioral strategies.

\section{ACKNOWLEDGEMENTS}

We thank the Conselho Nacional de Desenvolvimento Científico e Tecnológico (CNPq) for the research scholarship granted to PAGS (process 127543/2008-2) and EMXF (process 304077/2008-9). The Instituto Brasileiro do Meio Ambiente e dos Recursos Naturais Renováveis (IBAMA) for permission to conduct this study (collection permits 12734-1 - IBAMA/SISBIO). Wallisen T. Hattori for his invaluable help with statistical analyses of the data. Carlos F.D. Rocha, Arrilton Araújo, Luciano A. Anjos and anonymous reviewers for their insightful comments on the manuscript. David M. Hasset, owner of the Santuário Ecológico de Pipa, for providing us with hosting and to Helianne de Niemeyer by the picture of Coleodactylus natalensis.

\section{LITERATURE CITED}

Altmann, J. 1974. Observational study of behavior: sampling methods. Behaviour 40: 227-267.

Bergallo, H.G. \& C.F.D. Rocha. 1993. Activity patterns and body temperatures of two sympatric lizards (Tropidurus torquatus and Cnemidophorus ocellifer) with different foraging tactics in Southeastern Brazil. Amphibia-Reptilia 14: 312-315.
BOgerT, C.M. 1949. Thermoregulation in reptiles: a factor in evolution. Evolution 3: 195-211.

BOGERT, C.M. 1959. How reptiles regulate their body temperature. Scientific American 22: 213-221.

Bratтstrom, B.H. 1965. Body temperatures of reptiles. American Midland Naturalist 73: 376-422.

Capistrano, M.T. \& E.M.X. Freire. 2009. Utilização de hábitats por Coleodactylus natalensis Freire, 1999 (Squamata; Sphaerodactylidae) no Parque Estadual das Dunas do Natal, Rio Grande do Norte. PublICa 4: 48-56.

Colli, G.R. \& M.S. PAiva. 1997. Estratégias de forrageamento e termorregulação em lagartos do cerrado e savanas amazônicas, p. 224-231. In: L.L. Leite \& C.H. SAITO (Eds). Contribuição ao Conhecimento Ecológico do Cerrado. Brasília, Departamento de Ecologia Publishing, Universidade de Brasília, 326p.

Colli, G.R.; R.P. Bastos \& A.B. Araújo. 2002. The character and dynamics of the Cerrado herpetofauna, p. 223-241. In: P.S. Oliveira \& R.J. Marquis (Eds). The Cerrados of Brazil. Ecology and natural history of a neotropical savanna. New York, Columbia University Press, 424p.

Cowles, R.B. \& C.M. Bogert. 1944. A preliminary study of the thermal requirements of desert reptiles. Bulletin of the American Museum of Natural History 83: 265-296.

Dancey, C.P. \& J. ReIDy. 2006. Estatística sem Matemática para Psicólogos: usando o SPSS para Windows. Porto Alegre, Artmed Press, 608p.

Downes, S. \& R. Shine. 1998. Heat, safety or solitude? Using hábitat selection experiments to identify a lizard's priorities. Animal Behavior 55: 1387-1396.

EMPARN. 2010. Perfil do município. Empresa de Pesquisa Agropecuária do Rio Grande do Norte. Available online at: http://www.emparn.rn.gov.br/contentproducao/aplicacao/ emparn/principal/enviados/index.asp. [Acessed: 25/I/2010].

Freire, E.M.X. 1999. Espécie nova de Coleodactylus Parker, 1926 das dunas de Natal, Rio Grande do Norte, Brasil, com notas sobre suas relações e dicromatismo sexual no gênero (Squamata, Gekkonidae). Boletim do Museu Nacional 399: 1-14.

Freire, E.M.X.; G.O.S. Sugliano; M.F. Kolodiuk; L.B. Ribeiro; B.S. Maggi; L.S. Rodrigues; W.L.S. Vieira \& A.C.G.P. Falcão. 2009. Répteis Squamata das Caatingas do Seridó do Rio Grande do Norte e do Cariri da Paraíba: síntese do conhecimento atual e perspectivas, p. 51-84. In: E.M.X. Freire (Ed.). Recursos Naturais das Caatingas: uma visão multidisciplinar. Natal, EDUFRN, 239p.

Gandolfi, S.M. \& C.F.D. Rocha. 1998. Orientation of thermoregulating Tropidurus torquatus (Sauria: Tropiduridae) on termite mounds in an open area of south-eastern Brazil. Amphibia-Reptilia 19: 319-323.

Grover, M.C. 1996. Microhábitat use and thermal ecology of two narrowly sympatric Sceloporus (Phrynosomatidae) lizards. Journal of Herpetology 30 (2): 152-160. 
Howland, J.M.; L.J. VitT \& P.T. Lopez. 1990. Life on the edge: the ecology and life history of the tropidurine iguanid lizard Uranoscodon superciliosum. Canadian Journal of Zoology 68: 1366-1373.

HuEY, R.B. 1982. Temperature, Physiology and the Ecology of Reptiles, p. 25-91. In: C. Gans \& F.H. Pough (Eds). Biology of the Reptilia: physiological ecology. New York, Academic Press, 536p.

HuEY, R.B. \& M. SLATKIN. 1976. Costs and benefits of lizard thermoregulation. Quartely Review of Biology 51 (3): 363-384.

Huey, R.B. \& E.R. PIAnKa. 1983. Temporal separation of activity and interspecific

Overlap, p. 281-290. In: R.B. Huey; E.R. Pianka \& T.W. Schoener (Eds). Lizard Ecology: studies on a model organism. Cambridge, Harvard University Press, 501p.

Huey, R.B.; E.R. PIANKa \& J.A. Hoffmann. 1977. Seasonal variation in thermoregulatory behavior and body temperature of diurnal Kalahari lizards. Ecology 58 (5): 1066-1075.

JAKsIC, F.M. \& K. Schwenk. 1983. Natural history observations on Liolaemus magellanicus, the southernmost lizard in the world. Herpetologica 39: 457-461.

Kiefer, M.C.; M. Van Sluys \& C.F.D. Rocha. 2005. Body temperatures of Tropidurus torquatus (Squamata, Tropiduridae) from coastal populations: Do body temperatures vary along their geographic range? Journal of Thermal Biology 30 (6): 449-456.

Kiefer, M.C.; M. Van Sluys \& C.F.D. Rocha. 2007. Thermoregulatory behaviour in Tropidurus torquatus (Squamata, Tropiduridae) from Brazilian coastal populations: an estimate of passive and active thermoregulation in lizards. Acta Zoologica 88: 81-87.

Kohlsdorf, T. \& C.A. Navas. 2006. Ecological constraints on the evolutionary association between field and preferred temperatures in Tropidurinae lizards. Evolutionary Ecology 20: 549-64.

Licht, P.W.; R. Dawson; V.H. Shoemaker \& A.R. Main. 1966. Observations on the thermal relation of western Australian lizards. Copeia 1966: 97-110.

LisboA, C.M.C.A.; P.A.G. Sousa; L.B. Ribeiro \& E.M.X. Freire. 2008. Coleodactylus natalensis - clutch size; hatchling size. Herpetological Review 39: 221-221.

Maclean, W.P. 1985. Water-loss rates of Sphaerodactylus parthenopion (Reptilia:

Gekkonidae), the smallest amniote vertebrate. Comparative Biochemistry and Physiology 82: 759-761.

Magnusson, W.E. 1993. Body temperatures of field-active Amazonian savanna lizards. Journal of Herpetology 27 (1): 53-58.

Magnusson, W.E.; L.J. Paiva; R.M. Rocha; C.R. Franke; L.A. Kasper \& A.P. Lima. 1985. The correlates of foraging mode in a community of Brazilian lizards. Herpetologica 41: 324-332.

Mesquita, D.O. \& G.R. Colli. 2003. The ecology of Cnemidophorus ocellifer (Squamata, Teiidae) in a Neotropical Savanna. Journal of Herpetology 37: 498-509.
Mesquita, D.O.; G.C. Costa \& G.R. Colli. 2006a. Ecology of an Amazonian Savanna lizard assemblage in Monte Alegre, Pará State, Brazil. South American Journal of Herpetology 1 (1): 61-71.

Mesquita, D.O.; G.R. Colli; F.G.R. França \& L.J. VitT. 2006b. Ecology of a Cerrado lizard assemblage in the Jalapão region of Brazil. Copeia 2006 (3): 459-470.

Patterson, J.W. \& M.C. Davies. 1978. Preferred body temperature: seasonal and sexual differences in the lizard Lacerta vivipara. Journal of Thermal Biology 3: 39-41.

PiAnKa, E.R. 1971. Ecology of the agamid lizard Amphibolurus isolepis in Western Australia. Copeia 1971: 527-536.

Pianka, E.R. 1977. Reptilian species diversity, p. 1-34. In: C. Gans $\&$ D.W. TinkLe (Eds). Biology of the Reptilia. New York, Academic Press, 536p.

PIANKA, E.R. 1986. Ecology and Natural History of Desert Lizards. New Jersey, Princeton University Press, 209p.

PIANKA, E.R. \& L.J. VitT. 2003. Lizards: Windows to the Evolution of Diversity. Berkeley, University of California Press, 304p.

Rio Grande do Norte. 2006. Transforma parcela da Unidade de Conservação da Área de Proteção Ambiental - APA Bonfim/ Guaraíras, criada pelo Decreto Estadual n 14.369, de 22 de março de 1999, no Parque Estadual Mata da Pipa - PEMP, no município de Tibau do Sul e dá outras providências. Diário Oficial do Governo do Estado do Rio Grande do Norte Decree \#19341, 12 September 2006.

Ribeiro, L.B \& E.M.X. Freire. 2010. Thermal ecology and thermoregulatory behaviour of Tropidurus hispidus and $T$. semitaeniatus (Squamata, Tropiduridae) in a Caatinga area of northeastern Brazil. Herpetological Journal 20: 201-281.

Rосна, C.F.D. 1988. Ritmo de atividade e microclimatologia do habitat de Liolaemus

lutzae (Sauria: Iguanidae). Anais do Seminário Regional de Ecologia de São Carlos 4: 269-281.

RocHA. C.F.D. 1994. Introdução à ecologia de lagartos brasileiros, p. 39-57. In: L.B. Nascimento; A.T. Bernardes \& G. Cotta (Eds). Herpetologia no Brasil I. Belo Horizonte, Pontifícia Universidade Católica de Minas Gerais, Fundação Biodiversitas, 134p.

Rocha, C.F.D. 1995. Ecologia termal de Liolaemus lutzae (Sauria: Tropiduridae) em uma área de restinga do sudeste do Brasil. Revista Brasileira de Biologia 55: 481-489

Rocha, C.F.D. \& H. Bergallo. 1990. Thermal biology and flight distance of Tropidurus oreadicus (Sauria, Iguanidae) in an area of Amazonian Brazil. Ethology Ecology \& Evolution 2 (3): 263-268.

Rocha, C.F.D.; M. Van Sluys; D. Vrcibradic; M.C. KiefFer; V.A. Menezes \& C.C. Siqueira. 2009. Comportamento de termorregulação em labartos brasileiros. Oecologia Brasiliensis 13 (1): 115-131.

Sousa, P.A.G. \& E.M.X. Freire. 2010. Coleodactylus natalensis (NCN) Predation. Herpetological Review 41 (2): 218-218.

Sousa, P.A.G.; C.M.C.A. Lisboa \& E.M.X. Freire. 2010. Coleodactylus natalensis (NCN) Diet. Herpetological Review 41 (2): 218219. 
Steinberg, D.S.; S.D. Powell; R. Powell; J.S. Paemerlee Jr \& R.W. Henderson. 2007. Population Densities, Water-Loss Rates, and Diets of Sphaerodactylus vincenti on St. Vincent, West Indies. Journal of Herpetology 41 (2): 330-336.

VAN SLuYs, M. 1992. Aspectos da ecologia do lagarto Tropidurus itambere (Iguanidae) em uma área do sudeste do Brasil. Revista Brasileira de Biologia 52 (1): 181-185.

Vanzolini, P.E.; A.M.M. Ramos-Costa \& L.J. Vitt. 1980. Répteis das Caatingas. Rio de Janeiro, Academia Brasileira de Ciências, $161 \mathrm{p}$.

VITT, L.J. 1991. An introduction to the ecology of cerrado lizards. Journal of Herpetology 25: 79-90.

VITT, L.J. 1995. The ecology of tropical lizards in the Caatinga of northeast Brazil. Occasional Papers of the Oklahoma Museum of Natural History 1: 1-29.

VitT, L.J. \& C.M. CARVALHO. 1992. Life in the trees: the ecology and life history of Kentropyx striatus (teiidae) in the lavrado area of Roraima, Brazil, with comments on the life histories of tropical teiid lizards. Canadian Journal of Zoology 70: 1995-2006.

VitT, L.J. \& C.M. Carvalho. 1995. Niche partitioning in a tropical wet season: lizards in the Lavrado area of Northern Brazil. Copeia 1995: 305-329.

VitT, L.J. \& P.A. Zani. 1998. Ecological relationship among sympatric lizards in a transitional Forest in the northern Amazon of Brazil. Journal of Tropical Ecology 14: 63-86.
VitT, L.J.; P.A. ZANI \& A.M. BARRos. 1997. Ecological variation among populations of the gekkonid lizard Gonatodes humeralis in the western Amazon Basin. Copeia 1997: 3243.

VitT, L.J.; P.A. ZANI; T.C.S. Ávila-Pires \& M.C. Espósito. 1998. Geographical ecology of the gymnophthalmid lizard Neusticurus ecpleopus in the Amazon rainforest. Canadian Journal of Zoology 76: 1671-1680.

VitT, L.J.; R.A. Souza; S.S. Sartorius; T.C.S. Ávila-Pires \& M. C. Espósıto. 2000. Comparative ecology of sympatric Gonatodes (Squamata: Gekkonidae) in western Amazon of Brazil. Copeia 2000: 83-95.

VitT, L.J.; S.S. SARTorius; T.C.S. Ávila-Pires; P.A. Zani \& M.C. Espósito. 2005. Small in a big world: ecology of leaf-litter geckos in new world tropical forests. Herpetological Monographs 19: 137-152.

VitT, L.J.; W.E. Magnusson; T.C.S. Ávila-Pires \& A.P. Lima. 2008. Guia de Lagartos da Reserva Adolpho Ducke, Amazônia Central. Manaus, Áttema Design, 175p.

VRCIBRADIC, D. \& C.F.D. RochA. 1996. Ecological differences tropical sympatric skinks (Mabuya agilis and Mabuya macrorhyncha) in Southeastern Brazil. Journal of Herpetology 30: 60-67.

VRCibradic, D. \& C.F.D. Rocha. 1998. The ecology of the skink Mabuya frenata in an area of rock outcrops in Southeastern Brazil. Journal of Herpetology 32 (2): 229-237.

Submitted: 01.IV.2011; Accepted: 17.XI.2011.

Editorial responsibility: Kleber Del Claro 